\title{
A Trust Rooted in Ignorance: Why Ānanda's Lack of Understanding Makes Him a Reliable Witness to the Buddha's Teachings
}

\author{
Jonathan A. Silk
}

Whatever may be the truth of its posited etymological connection with the term "religion," there is no doubt that the Latin behind the English word "reliable" is religāre, originally meaning something like a strong binding together, later pointing to association and confident dependence. We normally judge persons-friends, for instance-to be reliable for various positive reasons, such as because of their wisdom, compassion or honesty, but it is probably rare that we place our deep trust and reliance in an individual because of their ignorance. But paradoxically, it may indeed sometimes be precisely ignorance that is held up in justification of faith. The present small contribution offers an example from the Indian Buddhist commentarial tradition of one such case. ${ }^{1}$

Canonically accepted Indian Buddhist scriptures-in the first place, sūtras - are universally held within the tradition to be reliable accounts of the salvifically potent teachings of the Buddha, and the reasoning behind this is relatively clear. A popular American Christian hymn of 1859 avers: "Jesus loves me- this I know, for the Bible tells me so."2 The same logic applies to Buddhist scriptures: the Buddha is to be trusted, he is omniscient, and he is infinitely compassionate-and we know this since the sutras tell us so. But how do we know that the scriptures themselves are reliable? No doubt precisely in order to forestall such potential challenges, Buddhist scriptures assert their reliability by means of an internal seal of their own authenticity, namely the stock phrase with which they regularly begin: "Thus I have heard" (evam mayā śrutam). Commentaries on Buddhist scriptures discuss this opening stock

1 I am preparing an extensive study of commentarial interpretations of the opening stock phrase of Buddhist sūtras, on which the present contribution may be seen as a report on one small issue. My thanks to my colleagues Rafal Felbur, Peter Szanto, Gregory Forgues, Berthe Jansen, and especially Michael Radich, for kind corrections, particularly to my translations, and to Maghiel van Crevel for suggestions toward clarity and style.

2 Wikipedia tells us that its author was the American Anna Bartlett Warner $(<\mathrm{https} / /$ en.wikipedia.org/wiki/Anna_Bartlett_Warner>), <https://en.wikipedia.org/wiki/Jesus_ Loves_Me>. Accessed 27.10.2019. 
phrase in detail, and interpret the "I" here to verify the validity of the ensuing discourse in the following manner: the account is authentic because the speaker, the Buddha's amanuensis (so to speak) and the compiler of his sermons (the samgitikāra, the reciter, that is, at the First Council), the monk Ānanda, who accompanied him through most of his preaching career, reliably reports what he heard directly from the Buddha-that is, he reports it thus (Sanskrit evam), precisely as he heard it. Ānanda, however, although he recounts and reports the teaching, is clearly not its author. He merely conveys. What becomes important for some commentators is the question whether Ānanda understood what the Buddha preached. The point of the present contribution is to show how the answer given by some commentators converts what could have been a potential weakness into a great strength, via what we might think of as a sort of rhetorical Aikidō.

The link between reliability and understanding is not limited to Buddhist lore. The great Indian Epic the Mahäbhārata contains a passage-which clearly very much post-dates the composition of its core-that depicts the seerpoet Vyāsa employing the elephant-headed god Ganeśa as his scribe. In this passage we read: ${ }^{3}$

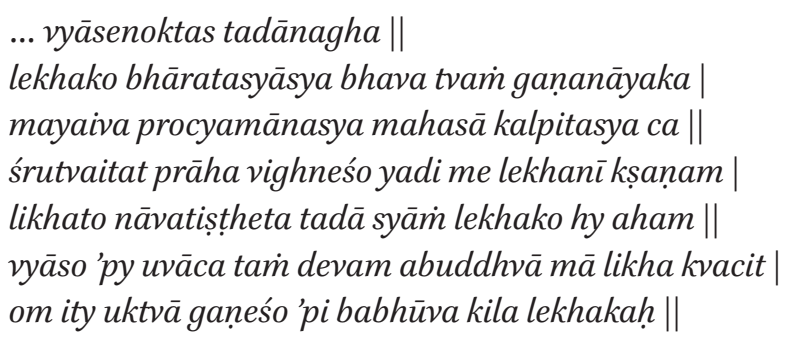

Vyāsa then said to him, "Ganeśa, you must be the scribe for this Bhārata as I compose it in my head and speak it forth." The lord of obstacles replied, "If my pen does not stop for an instant as I write, I shall be the

3 The passage, belonging only to a few of the collated manuscripts of the Mahäbhärata, is found in an appendix to Vishnu S. Sukthankar et al., The Mahäbhärata: For the First Time Critically Edited, vol. 1 (Poona: Bhandarkar Oriental Research Institute, 1933), 884, in the note to line 36 of passage 1, lines 6-12. The translation is that of James L. Fitzgerald, "India's Fifth Veda: the Mahābhārata's Presentation of Itself," Journal of South Asian Literature 20.1 (1985):125, and see also 138n11. See also the interesting observations of Bruno Lo Turco, "The Divine Scribe: A New Interpretation of the Gaṇeśa Episode from the Mahābhärata," in A. D’Ottone Rambach, ed., Rivista degli Studi Orientali n.s. 90 (2018) Supplemento 1, Palaeography Between East \& West. Proceedings of the Seminars on Arabic Palaeography at Sapienza University of Rome (Pisa \& Rome: Fabrizio Serra Editore), 153-78, many of which bear on questions of orality and related issues. I owe the idea to refer to this passage to my colleague Peter Bisschop. 
scribe." Vyāsa replied to the god, "But never write without having comprehended." "Om," said Ganeśa and he became the scribe.

The key phrase here is "never write without having comprehended" (abuddhva $m \bar{a}$ likha kvacit), a command to which Ganeśa formally agrees. For the author of this passage, it is essential that the scribe understand what he is recording. While this stipulation has been understood to justify the sometimes obscure or even corrupt passages in the text, another way to interpret it is to link the reliability of the whole Mahäbhätara to this initial complete comprehension of the Epic's first listener, and the individual to whom we owe our very knowledge of the text. Of course, it is perhaps needless to mention that, as for Ānanda so for the earlier reciters of the Mahäbhärata as well, the text was oral and not written, and thus this portrayal of the role of a scribe in a late addition to the Epic is absolutely anachronistic. Be this as it may, the question of interest to us here remains the same: does reliability rely on understanding?

All philologists are well aware of the dictum that it is better to have a manuscript of an ignorant scribe than a clever one, or rather we might say, one who thinks himself clever, for the clever scribe may attempt to correct or improve a text, while an ignorant scribe, perhaps transcribing nonsense, nevertheless offers the philologist the raw materials necessary to evaluate the underlying source. While there is, then, at least from the philologist's point of view, certainly something to be said for naive transmitters, one cannot correspondingly find that this is necessarily desirable in the oral transmission of the Buddha's sermons.

Now, some Indian Buddhist authors do seem to assume that, being in some respects the Buddha's closest disciple, Ānanda certainly well understood what his master taught. In fact, we find this stance even in canonical literature, that is, in a stratum of scriptural development at least logically, if not also chronologically, prior to the commentarial project. We read, then, the following in a passage in the Ekottārikāgama, perhaps relatively late as an Āgama text but nevertheless significantly earlier than the other materials we will notice here: 4

過去時, 諸佛侍者, 聞他所説, 然後乃解。然今日, 阿難比丘如來未發語, 便解。如來意須是不須, 是皆悉知之。由此因縁, 阿難比丘勝過去時諸 佛侍者。

4 T. 125 [35.5] (II ) 746c16-19, reading with the variant in the notes. I translated this passage on p. 199 as part of its larger context in Jonathan A. Silk, "Dressed for Success: The Monk Kāśyapa and Strategies of Legitimation in Earlier Mahāyāna Buddhist Scriptures," Journal Asiatique 291.1-2 (2004): 173-219, but here thanks to Rafal Felbur I have improved my understanding. 
In former times, the attendants of all buddhas listened to what [those] other [buddhas] preached, and only thereafter understood it. But in these days, the monk Ânanda already understands even before the Tathāgata speaks. He knows through and through everything the Tathāgata intends and does not intend [to convey]. For this reason, the monk Ānanda is superior to the attendants of all buddhas of former times.

Here it is emphasized that Ānanda did more than understand what the Buddha preached, he knew thoroughly everything that he meant (皆悉知之), and for this reason Ānanda is superior even to all attendants of former Buddhas. But perfect understanding is not necessarily obligatory, since it is also taken as a given that the understanding of even the most accomplished disciple is, in some respects, not equal to that of a buddha. In the Pāli commentarial tradition, the relevant portion of the interpretation of the opening stock phrase in commentaries attributed to Buddhaghosa runs as follows: ${ }^{5}$

vāyam idha ākāranidassanāvadhāraṇesu dațthabbo |

tattha ākāratthena evamisaddena etam atham dīpeti nānānayanipunam anekajjhāsayasamutțhānam atthabyañjanasampannaì vividhapātihāriyam dhammatthadesanāpațivedhagambhïraim sabbasattānam sakasakabhāsānurūpato sotapatham ägacchantam tassa bhagavato vacanam sabbappakārena ko samattho viññātuṁ sabbathāmena pana sotukāmatam janetvāpi evaì me sutam mayāpi ekenākārena sutan ti $\mid . .$.

evam me sutan ti iminā pana sakalena vacanena āyasmā ānando tathāgappaveditam dhammai் attano adahanto asappurisabhümim atikkamati sāvakattam patijānanto sappurisabhümim okkamati| tathā asaddhammā cittam vutțhāpeti saddhamme cittam patițthāpeti | kevalam sutam evetam mayā tasseva pana bhagavato vacanan ti dīpento attānam parimoceti satthāram apadisati jinavacanam appeti dhammanettim patițthāpeti|

api ca evaì me sutan ti attanā uppāditabhāvam appatijānanto purimavacanam vivaranto sammukhā pațiggahitam idam mayā tassa bhagavato catuvesārajjavisāradassa dasabaladharassa āsabhaț̣nānațțāyino

5 All four of Buddhaghosa's Nikāya commentaries are here virtually identical; see the beginnings of the commentaries on the first suttas in the Sumangalavilāsin̄̄, Papañcasūdanī, Manorathapūraṇī, and Sāratthappakāsinī. I consulted the editions of the Vipassana Research Society, Igatpuri India, 1993-1995. My debt to the translation of Peter Masefield, The Udāna Commentary (Parammatthadīpañ nāma Udānațthakathā) by Dhammapala, vol. 1 (Oxford: Pali Text Society, 1994), 21, 35-36 (with detailed notes, $15^{-1} 5^{2}, 172-73^{-86}$ ), is profound. 
sīhanādanādino sabbasattuttamassa dhammissarassa dhammarājassa dhammädhipatino dhammadīpassa dhammasaranassa saddhammavaracakkavattino sammāsambuddassa vacanam na ettha atthe vā dhamme vā padevābyañjanevākan்kā $v \bar{v}$ vimativākattabbātisabbadevamanussānam imasmim dhamme assaddhiyam vināseti saddhāsampadam uppādeti $\mid$

[There are many senses in which the word "Thus," evam, can appear.] Here [in the context of the opening phrase of a scripture] this same [word, which has many meanings] should be seen as depicting (1) manner, (2) explanation, and (3) emphatic affirmation.

With respect to that [list of possible senses, Ānanda] using the word "Thus" illustrates this sense in the meaning of (1) manner [as follows]: Who is capable of cognizing in all its aspects the speech of the Blessed One, [speech which is] subtle in its many methods, that arises [to accord with] the many aspirations [of beings], that is perfect in letter and sense, [productive of] diverse miracles, profound in its teaching, sense, instruction and intellectual penetration, and which reaches the ears [of beings] in conformity with their own individual manner of speech? [No one is really capable of doing so,] still, with all my strength producing [in others] the desire to hear [the preaching], [I say] "Thus I have heard, [meaning] I too have heard in one particular manner [although there are other aspects of the teaching I have not grasped]." ...

Again, with the entire expression "Thus I have heard" the Venerable Annanda, not appropriating as his own the Teaching revealed by the Tathāgata, transcends the stage of the unworthy person, and asserting his status as an Arhat enters the stage of the worthy person. Thus he turns his mind away from what is not the True Teaching, and settles his mind in the True Teaching. Illustrating the claim "all this was only heard by me, while the expression is that of the Blessed One," he frees himself [from any blame], refers to the teacher [the Buddha, as the source of the teaching], points to the expression of the Victor [as the authority], and establishes the Teaching as the guide.

Moreover, denying with the words "Thus I have heard" that [the contents of the scripture] are something produced by himself and disclosing that [they are rather] past utterances [of the Buddha], [he says] "I received this expression face-to-face from the Blessed One ... [and so] in this regard there should not be any doubt or perplexity with regard to meaning, doctrine, word or letter," so removing disbelief in this Teaching from all gods and humans and producing an excellence of belief [in that Teaching]. 
Here we see clearly that for this commentarial tradition, Ānanda avers that while he cannot fathom the Buddha's teaching in its entirety, nevertheless he does his very best. Moreover, he is, for this commentary, an Arhat, an individual on the stage of a worthy person (sappurisabhümi), that is to say, well advanced on the path, an issue to which we will return below, since it holds the key to our argument. So for Buddhaghosa - or let us say more carefully, for the tradition which records its ideas under his name-Ānanda understood as much of the Buddha's teaching as was possible for any non-buddha, yet he claims no role in the production of the preaching which he heard, remembered and transmits. His reliability hinges on his accurate transmission of what he heard directly, and his strict transmission of only that.

In a similar vein, the later Pāli commentator Dhammapāla in his remarks on the Udāna offers the following: ${ }^{6}$

me sutan ti sāvakasampattim savanasampattiñ ca niddisati pațisambhidāpattena pañcasu thānesu bhagavatà etad agge thapitena dhammabhaṇ̣̂āgārikena sutabhāvadīpanato tañ ca kho mayāva sutam்na anussutikaim na paramparābhatan ti imassa catthassa dīpanato |

"I have heard" shows [Ānanda's] excellence as an auditor and [his] excellence at hearing, since it illustrates the fact that it was heard by one who has mastered the [four] special knowledges, one who was placed first by the Blessed One in five categories, ${ }^{7}$ the treasurer of the Teaching, and since it illustrates this sense by saying "And that I myself heard; it is not hearsay, it was not passed down in a traditional lineage."

Here, even more emphatically than in Buddhaghosa's text, the excellences of Ānanda are emphasized, and his profound understanding is brought forward as a reason to trust him. Ānanda is a special individual, and by virtue of his mastery reliable, though again, his role as transmitter is not overlooked.

The same notion is found in the (mostly but not exclusively Mahāyāna) commentarial traditions to which we now turn, first (chronologically) in Jñānagarbha's eighth-century Anantamukhanirhāradhāraṇi-țīkā, in which,

6 Udānațthakathā, also cited after the edition of the Vipassana Research Society. The date of Dhammapāla is not known, but Kenneth Roy Norman, Pāli Literature: Including the Canonical Literature in Prakrit and Sanskrit of All the Hinayāna Schools of Buddhism (Wiesbaden: Otto Harrassowitz, 1983), 137, speculatively puts him in the middle of the sixth century, and Oskar von Hinüber, A Handbook of Pāli Literature (Berlin: Walter de Gruyter, 1996), §307, 370, in the second half of the same century.

7 I believe the reference is to Anguttara-nikāya i.24-25 (I.xiv.4), in which five categories are listed in which Ānanda is the first among monks. All other monks listed are mentioned under just one heading. Masefield, The Udāna Commentary, has no note. 
in commenting on the portion of the expression which follows "Thus have I heard" - namely, "at one time" or "on one occasion," ekasmin samaye - the commentator states that this expression may be construed either with the preceding verb "heard" or with the following "dwelt." That is, Jñānagarbha understands that the scripture begins by stating either that Annanda heard the Buddha preach at one time, or that the Buddha on a certain occasion dwelt in a specific place, at which he preached. Therefore, Jñānagarbha states: ${ }^{8}$

de yang gang gi tshe gong ma dang sbyar na de'i tshe 'khor rnams kyi nges pa bskyed pa'i phyir bdag nyid mang du thos par bstan te |'di ltar bdag gis dus gcig na thos kyi | dus gzhan na yang gzhan dag thos so || de bas na bdag ni mang du thos pa yin te | de'i bdag gi tshig ni yid ches par bya ba yin par bstan pai phyir ro $\|$

When the [statement of time] is related to the preceding [clause], in order to produce certainty in the assembly it is taught that he himself [Ānanda] has heard much (*bahuśruta) [= is very learned]. Because it is taught: "Thus I have heard at one time, but at other times I heard other things. Therefore I have heard much [= I am very learned], and the speech of such an individual as I is trustworthy."

Here the Tibetan yid ches par bya ba perhaps points to something like Sanskrit pratyetarya, and means "is to be trusted or believed in." The speaker Ānanda is made to assert, quite directly, his trustworthiness and reliability, solidly based in his learning.

Several other commentators also emphasize the great learning of Ānanda as a basis for his trustworthiness, but as I have discussed the status of Ānanda as a reliable witness in detail elsewhere, ${ }^{9} \mathrm{I}$ here concentrate instead on another interesting approach taken by one line of commentarial tradition which turns what should, we might imagine, have been a great handicap into the ultimate virtue.

The problem is this: tradition holds that Ānanda, at the time of the Buddha's death and until immediately before the opening of the so-called First Council, was not an Arhat, that is, he was not awakened. (When the Pāli commentary cited above refers to him as an Arhat, it is anachronistic, since this attainment comes only after the Buddha's death.) Ānanda was even at first refused entry

8 Hisao Inagaki, The Anantamukhanirhāra-Dhāraṇi Sūtra and Jñānagarbha's Commentary (Kyoto: Nagata bunshodo, 1987), 116.1-6.

9 Jonathan A. Silk, "Possible Indian Sources for the Term Tshad ma'i skyes bu as Pramānapuruṣa," Journal of Indian Philosophy 30.2 (2002): 111-6o. 
into the Council, disqualified to join this conference of saints because of his lack of ultimate understanding. How, therefore, being himself unable to access the real meaning of the Buddha's teaching, could he be relied upon to transmit that teaching to others?

Passages hinting at the crucial formulation are found for perhaps the first time in the late eighth century commentaries of Kamalaśila. In his commentary on the the Śalistamba-sūtra he writes: ${ }^{10}$

bdag gis thos pa zhes bya ba 'di gnyis kyis ni | bdag gis mngon sum du thos pa dang | rtogs pa ma yin par ston te | bdag nyid kyis thos kyi thos pa gcig nas gcig du brgyud pa las 'ongs pa ni ma yin no || thos suzad kyi rtogs pa ma yin te | sangs rgyas ma gtogs par gzhan kyis 'di lta bu'i don rtogs mi srid pa'i phyir ro || de yang yid ches par bya ba'i rgyu yin te | gzhan du na mi srid pa'i don smras nayid ches par mi gyur ro \|

These two [words], "I heard," indicate that I heard directly and that I did not understand [its meaning]; I myself heard, but what was heard is not passed down through a traditional lineage from one person to another. It was merely heard, but not understood, because it is impossible that another besides the/a Buddha [could] understand a matter such as this. That [statement that the reciter is not responsible for the contents, but rather the Buddha himself $]^{11}$ also is a cause for inducing belief; otherwise, if an impossible matter were stated, it would not be convincing.

We are fortunate that, in the absence of a known Sanskrit version of this commentary, we do have a Chinese translation, produced by the famous 'Gos Chos grub (Chinese Facheng 法成), a bilingual monk living in Tibetan-occupied Dunhuang in the ninth century. ${ }^{12}$ In light of the fact that Kamalaśila lived in

10 Jeffrey D. Schoening, The Śălistamba Sūtra and Its Indian Commentaries (Vienna: Arbeitskreis für Tibetische und Buddhistische Studien, Universität Wien, 1995), 455·4-9.

11 See Schoening, The Śălistamba Sūtra, 202 n. 9.

12 The existence of this translation was discovered by Yoshimura Shūki 芳村修基, and edited by him in a bilingual edition, Kamarashīra-cho Daijō Tōkangyō no Chūshaku: Chibetto-bun to Hōjō-shi no Kanshakubun Taishōカマラシーラ著大乗 稲芋經の註釋: チベ ツト文と法成師の漢釋文對照 (Kyoto: Ryūkoku Daigaku Tōhō Seiten Kenkyūkai, 1959). It was studied by Ueyama Daishun 上山大峻 in his comprehensive study of Chos grub, "Daiban-koku Daitoku Sanzō Hōshi Shamon Hōjō no Kenkyū" 大蕃國大徳三藏法 師沙門法成の研究, Tōhō Gakuhō 東方學報 38 (1967), 133-98; 39 (1968), 119-222. Reprinted in Ajia Bunkashi Ronsō アジア文化史論叢 I [Contributions to West, Central and North Asian Studies: Collected Papers of Liu-sha Hai-hsi (流沙海西) Scholarship Prize Winners] (Tokyo: Yamakawa shuppan, 1978), 1-179; in the latter the relevant pages are $96-105$. 
the late eighth century, and that Facheng was active during the Tibetan occupation of Dunhuang around $780-850$, we may tentatively conclude that our manuscripts of the text date almost to the lifetime of Kamalaśla himself. The Chinese version corresponding to that translated above from Tibetan has the following: ${ }^{13}$

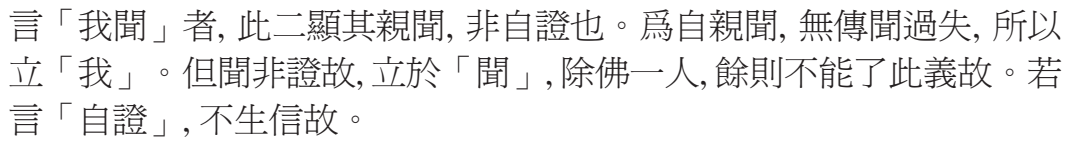

As for saying "I heard," these two [words] make clear that he heard it directly, and not that he himself understood it. As he himself directly heard it, without errors of transmission, thus [the text] speaks of "I." Because he merely heard it, but did not understand it, [the text] speaks of "hearing," because with the sole exception of the/a Buddha, no one is capable of fully penetrating this meaning. So if [the text] were to say "I understood," this would not engender trust [in the audience].

The argument is clear: if Ânanda were to claim his own presentation of the teaching, when difficult points would arise, listeners would doubt their validity and veracity. Only by denying not only authorship but even understanding, and maintaining that his role is nothing more than accurately transmitting what the Buddha said, can Ānanda ensure the trustworthiness of his account. His reliability, therefore, is assured precisely by his lack of (complete) understanding. We might, then, articulate this argument more fully as follows: If I, Ānanda, were to claim understanding, you might wonder whether I were paraphrasing the Buddha's teachings, and then, when you had doubt, you might blame me. But I do not claim understanding or authorship, and my own lack of understanding (which you will expect, knowing that I am not an Arhat) assures this.

In his commentary on the Vajracchedikā, Kamalaśila deploys some of the same terminology as that in the passage quoted immediately above, and seen earlier in a Pāli passage: ${ }^{14}$

13 Dasheng Daoyujing suiting shoujingji 大乘稻芋經隨聽手鏡記, T. 2782 ( LXXXV) 546c1417. The facing Chinese and Tibetan texts are found in Yoshimura, Kamarashïra-cho Daijō Tōkangyō no Chūshaku, 35-38. Ueyama, "Daiban-koku," 101, contains a table with a Japanese translation of our passage from the Tibetan (of the Peking Tanjur) and the corresponding Chinese text (from the Taishō edition), with the correspondences marked in the Chinese (although not entirely clearly).

Derge Tanjur 3817, shes phyin, ma, 205a4-5; Dh = IOL Tib J 17757 b1. 
thos pa zhes bya ba nirtogs pa dgag par byed de | sangs rgyas ma gtogs par chos 'di lta bu dag rang gis rtogs pa gzhan med pa'i phyir ro \|| 'dis ni yid mi ches pa sel bar byed do \|

"Have heard" eliminates [the notion of the contents being] understood, because besides the/a Buddha there is none other who can understand such teachings as these on his own. This clears up [whatever] distrust [there might be in the authority of the teachings].

Again, in his Saptaśatikā-Prajñāpāramitā-țikka Kamalaśilla expresses the same idea in slightly different terms: ${ }^{15}$

thos pa zhes bya ba ni rna ba'i rnam par shes pas rjes su myong ba yin gyi rtogs pa nima yin te | chos 'di lta bu de bzhin gshegs pa ma gtogs par gzhan gyis khong du chud pa'i mthu med pa'i phyir ro \|

"Have heard" means experienced through the aural cognition ("śrotravijñanna), but not 'understanding,' because no one other than the/a Tathāgata has the power to fully comprehend teachings such as this.

Finally, in his Avikalpapraveśadhāraṇi-țīkā Kamalasilla refers to others who heard and transmitted sūtras from the Buddha, asserting that like Ānanda they too did not fully understand what they heard: ${ }^{16}$

thos pa zhes bya ba 'dis ni bdag gis ma rtogs so zhes bya ba bstan pa ste | thos par zad kyi rtogs pa med par rnam pa gcod pa'o || chos kyi dbyings thugs su chud pa 'phags pa 'jam ba'i dbyangs la sogs pa theg pa chen po yang dag par sdud par byed par grags mod kyi |'on kyang sang rgyas dang 'dra bar 'di 'dra ba'i chos rnam pa thams cad du rtogs pa gzhan la mi srid de $\mid$ de bas na de dag gis kyang | bdag nyidyang dag par sdud par byed par khas blangs pas mdo sde'i don rnam pa thams cad du ma rtogs so zhes ston to $\mid$ gzhan du na ni de nyid ston pa por'gyur te | yang dag par sdud par byed pa ma yin no || de nyid ni yid ches par byed pa'i rgyu ste | gzhan du na mi srid pa'i don smras na yid ches par mi 'gyur ba'i phyir ro \|

With this "Have heard" [the reciter] indicates "I did not understand"; this specifies that [I] only heard but am without understanding. Although the

\footnotetext{
15 Derge Tanjur 3815, shes phyin, ma 89b3-4.

16 Derge Tanjur 400o, mdo 'grel, ji, 124b4-7.
} 
Noble Mañjughoșa and others who comprehend the dharmadhātu are indeed celebrated as reciters of Mahāyāna [scriptures], nevertheless those other [than the/a Buddha] do not have the comprehensive understanding in all its aspects of such a teaching as does the/a Buddha, and therefore since they too acknowledge "I indeed am [no more than] a reciter," this indicates that [they] do not understand the meaning of the scripture in all its aspects. Otherwise, the focus here would be on the teacher, not the reciter. Precisely [the reciter] is the cause of inspiring confidence, since otherwise if [some seemingly] impossible matter were mentioned, there would be no confidence.

Here Kamalasíla offers an example of the kind of difficult teaching he imagines might provoke doubt in an audience, namely the idea that some things are, or seem to be, impossible (*asambhava?). As above, if upon encountering such a teaching one were required to trust Ânanda or another reciter as the ultimate authority, one might hesistate to trust the truth of the teaching, a potential problem avoided by stressing that both the teaching and its interpretation are solely the responsibility not of the fallible reciter but rather of the Buddha, who is of course omniscient and inerrant.

Viryaśrīdatta, also belonging to the eighth century and author of the $\mathrm{Ni}$ bandhana commentary to the Arthaviniścaya-sütra (incidentally a nonMahāyāna text, demonstrating that the arguments offered here are in no way exclusively Mahāyāna), begins to point out the logic at play in this argument, when he writes: ${ }^{17}$

śrutam iti śrotravijñ̄anenodgrhittam | anena tasmin sambhave 'dhigamābhāvam darśayati | paścād adhigamasambhave balavaiśāradyādīnām buddhadharmāṇām āvenikānām anabhisamayāt śrutam iti na virudhyate |

"Have heard" means acquired by aural cognition. This points out with this [expression] that on that occassion he had not obtained the state of comprehension [of the teaching, he merely heard it]. Even if there is the possibility of comprehension later [after the Buddha's death, when Ānanda finally became an Arhat], because [at the time he heard this preaching] he had not realized the particular qualities definitive of a

17 N.H. Samtāni, The Arthaviniścaya-sūtra and Its Commentary (Nibandhana) (Patna: K. P. Jayaswal Research Institute, 1971), 75.5-8. I read with the manuscript sambhave against the editor's samaye. 
buddha, the powers, fearlessnesses and so on, it is not inconsistent to say "Have heard" [rather than "understood"].

What is explicitly denied here is any adhigama, "understanding" or perhaps even better "mastery." Ānanda is not an Arhat at the time he hears the Buddha's teachings, so he cannot claim to have understood them, only to have heard and memorized them.

Another (anonymous) commentary to the same scripture, the Arthaviniścaya-țikā, goes all the way and connects the dots: ${ }^{18}$

thos zhes bya ba ni rna ba'i dbang po rnam par dag pa dang ldan pa'i rna ba'i rnam par shes pas don dang tshig ma nor bar gzung zhes bya ba'i don te | des ni khong du chud pa med par ston to || de ci'i phyir zhe na |gang gi tshe bcom ldan 'das las 'phags pa dga' bos mdo 'di mngon sum du thos pa de'i tshe | 'phags pa dga' bos bden ba rtog pa med de bcom ldan 'das mya ngan las 'das pa'i 'og tu bden pa mthong ba'i phyir ro \|

"Have heard" means the meaning and the words were grasped without error by the aural cognition possessing the correct faculty of hearing, and not understood [by the reciter, who has merely reported and not interpreted through his understanding]. Why? Because at the time when the Noble Ānanda heard this scripture directly from the Blessed One the Noble Ānanda lacked understanding of the truth, and [only] after the nirvāna of the Blessed One did he come to see the truth [and become an Arhat].

Although we need not consider the complex and in some respects different Buddhist tantric tradition in detail here, in order to illustrate the generalities of this view across Buddhist traditions we might just briefly cite from the tantric Candrakīrti, who in his Pradipoddyotana commentary to the Guhyasamājatantra says the following: ${ }^{19}$

mayeti sākșān na paramparayā śrutaì nādhigatam|

"I" means that it was heard directly personally by me, not through a traditional lineage, nor did I understand it.

18 Derge Tanjur 4365, sna tshogs, nyo za7-b1.

19 Anonymous edition in Dhịh 48 2009, 132.15. This is apparently a revised edition of Chintaharan Chakravarti, Guhyasamājatantrapradīpodyotanațīkā-șațkoțivyākhyā (Patna: K.P. Jayaswal Research Institute, 1984), in which the passage with several mistakes is found at $11.25^{-26 .}$ 
Finally, while not, to be sure, an Indian text, the Korean Wŏnch'ŭk's (613-696) 圓測 commentary on the Sandhinirmocana-sūtra, the Haesimmilgyŏng so 解深 密經疏, is nevertheless worthwhile briefly noting for its treatment of the relevant portion of the opening passage: ${ }^{20}$

又微細律明其阿難當登高座出法藏時, 身即如佛, 具諸相好。若下高座, 還復本形。眾見此瑞, 有三種疑。一疑, 大師釋迦, 以慈悲故, 從涅槃起, 更宣深法。二疑, 諸餘世尊從他方來。三疑, 阿難比丘既是佛弟, 堪代其 兄, 轉身成佛。今欲遣三疑, 故云「如是我聞」等七事。明 $「$ 乃是我親 從佛聞, 非關慈悲從涅槃起, 亦非餘佛他方來, 又非我已轉身成佛, 自說 經也」。

Again, the Kșudrakavastu of the [Mūlasarvāstivāda] Vinaya tells the story that at the time when Ānanda was about to mount the high seat to proclaim the Dharmapitaka [at the First Council], his body was just like that of the/a buddha, replete with the major and minor bodily marks. When he descended from the high seat, his body returned to its original form. When the assembly saw this wonder, they had three kinds of doubts. 1. They wondered whether the great Śăkya teacher, out of compassion, had arisen from nirvāna to once again proclaim the profound teaching. 2. They wondered whether other Blessed Ones had come from another world. 3. They wondered whether the monk Ānanda, being the younger brother of the Buddha, had been able to take the place of his elder brother, transform his body and become a buddha. Now, in order to remove these three doubts [Ānanda] states the seven items [making up the nidāna] beginning "Thus I have heard." He does so to clarify that "Precisely, I heard it directly from the Buddha; it is not the case that out of compassion he arose from nirvanna; it is not that other buddhas came from elsewhere; and again it is not that I myself transformed my body, became a buddha and [now] preach the sūtra myself."

Here in this rich passage the text makes clear that in no way is the teaching to be attributed to Ānanda and that, while his preaching might be confused with

20 Found in the Zokuzōkyō, X21no369_po18ob12-19, online at <http://tripitaka.cbeta.org/ X21no369_oo1>. Its Tibetan translation at Derge Tanjur 4016 was made from the Chinese by the above-mentioned Facheng, this passage being found at mdo 'grel, $t i 38 \mathrm{a} 2-6$. When the Chinese is open to interpretation I allow myself to be guided by the Tibetan. A very similar though abbreviated version is found in the Ârya-Lañkāvatāra-nāma-mahāyānasūtravrțti Tathāgatahrdayālamikāra-nāma attributed to Jñānavajra, Derge Tanjur 4019, mdo 'grel, pi 6b3-6; I do not know if the debt of this commentary to that of Wŏnch'ŭk has been studied. 
the preaching of a present buddha, perhaps because the act of preaching carries with it such gravitas, Annanda was no buddha and did not preach on his own accord, offering merely a repetition of what he had learned.

The lesson to be gained from the short survey here is that commentators within the Buddhist tradition faced a problem: Annanda is the authority for the Buddha's teaching for later audiences, since it was he who recited the sermons at the First Council, where they were canonized. However, he was known by the tradition to have been unawakened during the Buddha's lifetime, that is, at the time he actually heard these preachings. The authority for the Buddha's word, then, was explicitly not authoritative. But this is where the genius of the commentarial mind shows itself: what could have been a weakness-and we might contrast the thoroughly comprehending Ganeśa here-is deftly turned into a strength: it was precisely Ânanda's lack of ability to understand, and thus inability to paraphrase, to cite one key implication, that made necessary his rote recital, and it is precisely this, in turn, that made possible all later access to the exact words spoken by the Buddha: all reliable transmission of the Buddha's teachings, and our consequent justified confidence in that transmission, was made possible precisely and only by Ānanda's ignorance.

The brief series of passages surveyed here raises a small but interesting point in the rhetoric and exegetical logic of Buddhist commentarial tradition, which in a broader frame is, of course, unsurprising: nothing in the tradition cannot be explained (away) as perfectly in harmony with a grand plan, so to speak, or put another way, there are no inconsistencies, if only one looks from the correct perspective. (This attitude is of course not unique to the Buddhist tradition, and one might think immediately of the Talmudic traditions as offering another vivid example of the same reasoning.) It is well known that in many circumstances Buddhist authors appeal to the notion of skillful means (upāya), through which any apparent inconsistency or contradiction in the Buddha's teaching may be shown to be nothing other than a manifestation of the flexibility and adaptability of his salvific efforts. The approach in the passages cited above is different, but in at least one dimension similar: what seems like a problem is shown, when seen correctly, to be not a deficiency but rather on the contrary its polar opposite, an essential building block of the tradition. The trust engendered by this logic is the key to the strong binding that defines reliability, something one feels as well, though on a less empyrean level perhaps, with friendship. It is, of course, needless to say that most feelings of respect, trust and appreciation do not normally stem from perceptions of ignorance or other weaknesses, and they require no rhetorical gymnastics to justify their counterintuitive conclusions. Indeed, if we can trace their roots at all such feelings appear to grow from shared worldviews, perhaps manifest in a 
sense of humor or common value system. With all this in mind, it is with overwhelming pleasure that, with sincerest wishes for the long continuation of a real bond of heartfelt friendship, I offer this small paper to the health and happiness of my dear friend Albert Hoffstädt. 